\title{
Ergonomics Analysis and Social Demographic Factors Associated with Welder in Small-scale Workshops in Makassar, Indonesia
}

\section{Ilham Bakri¹, Rani Aulia Imran¹, Mulyadi1, and Andi Eifan Abuswan Fikramudyah²}

${ }^{1}$ Ergonomics, Works Design, and Occupational Safety \& Health Laboratory, Industrial Engineering Department, Hasanuddin University, J. Perintis Kemerdekaan Km. 10, Tamalanrea Indah, Tamalanrea, Tamalanrea Indah, Tamalanrea, Kota Makassar, Sulawesi Selatan 90245, Indonesia ${ }^{2}$ Department of Industrial Engineering, Hasanuddin University Jl. Perintis Kemerdekaan Km. 10, Tamalanrea Indah, Tamalanrea, Tamalanrea Indah, Tamalanrea, Kota Makassar, Sulawesi Selatan 90245, Indonesia

\section{Abstract}

Welding is an important process of steel fabrication. Even though welder is associated with various occupational hazards, there is limited information of work-related health

Corresponding Author: Rani Aulia Imran raniauran14@gmail.com

Received: 15 May 2018 Accepted: 3 June 2018

Published: 19 June 2018

Publishing services provided by Knowledge

(c) Ilham Bakri et al. This article is distributed under the terms of the Creative Commons

Attribution License, which permits unrestricted use and redistribution provided that the original author and source are credited.

Selection and Peer-review under the responsibility of the ICOHS 2017 Conference Committee.

\section{G OPEN ACCESS} problems within this occupational group. This study aimed to gather information about occupational hazards, use of personal protective equipment, and demographics among small-scale welding workshops. A work site-based cross-sectional study was conducted at 34 small-scale welding workshops in Makassar, Indonesia. Interviews, questionnaire, and direct observation used to collect data on demographic characteristics, occupational hazards, and musculoskeletal disorder experience. The demographic factors that were collected were age, work duration, educational status, work experience, technical training, safety tools, also smoking and drinking habit. Working posture assessed using OWAS and level of musculoskeletal disorder using Nordic body map. Descriptive statistics and bivariate logistic regression was used for correlations analysis. In general, result indicated that workers were $34 \pm 11$ years old, 66 percent married, 78 percent smoking, 22 percent had drinking habit, 56 percent had grade school education or less, 66 percent were employed for more than 4 years, 73 percent worked less than 8 hours a day, 95 and 84 percent, respectively, did not take safety training and safety awareness. Work condition assessed concludes that 36 percent of participants perceived the temperature was hot, 47 percent noisy, 66 percent illuminations were good enough, and 44 percent did not use chair to support them. Nordic body map and OWAS posture analysis indicated that 51 percent welders were experiencing moderate level of musculoskeletal complaint and 55 percent welders were category 3. Nevertheless, the only factor having a significant value associated with musculoskeletal symptoms was working posture $(p$-value $=0.030)$. Welders in this study were experiencing musculoskeletal complaint of back pain, hip, forearm, buttock, and shoulder; which OWAS suggest need improvement immediately. Further research needed within this occupational group to improve working posture, safety, and protective equipment awareness, also avoiding musculoskeletal disorder.

Keywords: welder, small-scale workshop, posture, musculoskeletal disorder, OWAS, occupational safety 


\section{Introduction}

Small and Medium Enterprises (SMEs) plays important role to improve Indonesia's economic growth and contribute considerably to employment of the local communities $[1,2]$. Employment absorption in SMEs or informal sector increase to 97.22 percent in the last five years periods of more than 110 million people of total workers $[3,4]$. National data from Center Biro of Statistics (BPS) in 2016 reflect that Indonesian SMEs sector were reaching 56.5 million enterprises [4]. Unfortunately, the increasing of this sector also parallels with high occupational accident and injury cases.

The number of occupational accidents and injuries in Indonesia are quite high. Based on the BPJS Ketenagakerjaan data, number of accidents in 2016 reached 101,367 cases. More than 50 percent cases occur within the company when they work, and the others were outside the work areas and road accidents $[4,5]$. SMEs face serious occupational health and safety challenges [6]. Another survey noted about 80 percent of informal workers does not have social security or insurance [7]. This situation is very alarming given that the economic activities of the informal sectors are exposed to work and health risk. This is implying that total accident and injury cases could be higher, if include non-reported data.

According to the World Bank, SMEs can be grouped as a small-scale with less than 30 workers and medium scale with maximum 300 workers [2]. One of small-scale business which is currently developing in Makassar, Indonesia, is welding workshop. Welding is an important process of steel fabrication and the most common way to connect metal parts permanently [9]. Even though welder is associated with various occupational hazards, ergonomics considerations in developing country are not taken seriously [10]. Welding workshop in Makassar, serves welding products/constructions such as iron fence/doors, security/window trellis, stairs, canopy, roof truss and others.

Interview result by Suprianto \& Evendi [8] found that most welder of SMEs (66.7\%) experienced about 6-10 injuries types at workplace, such as blistered skin, electrocuted burns, bump, discomfort, and eye pain. Finding by Tadesseet al. [9] include breathlessness, cough and fever, also hearing impairment. Most studies conclude that welder is exposed to several hazards, namely: intense bright light, intense heat, electricity, excessive noise, vibrations, high temperature, welding fume and gases, and awkward work postures $[9,10]$. Welding also often requires awkward work postures [6] and combines with some organizational problems such as exceed working hours and unsafe working condition scan lead to musculoskeletal disorder [11]. However, there is limited information on use or work related health problems within this occupational 
group. This study aimed to gather information about occupational hazards, use of personal protective equipment and demographics characteristics among small-scale welders in Makassar, Indonesia.

\section{Methods}

Seventy three welders participated from 34 of 50 welding workshop spread across 14 districts in Makassar City (Figure 1). They have been involved in a work site-based cross sectional study of welding workshops SMEs.

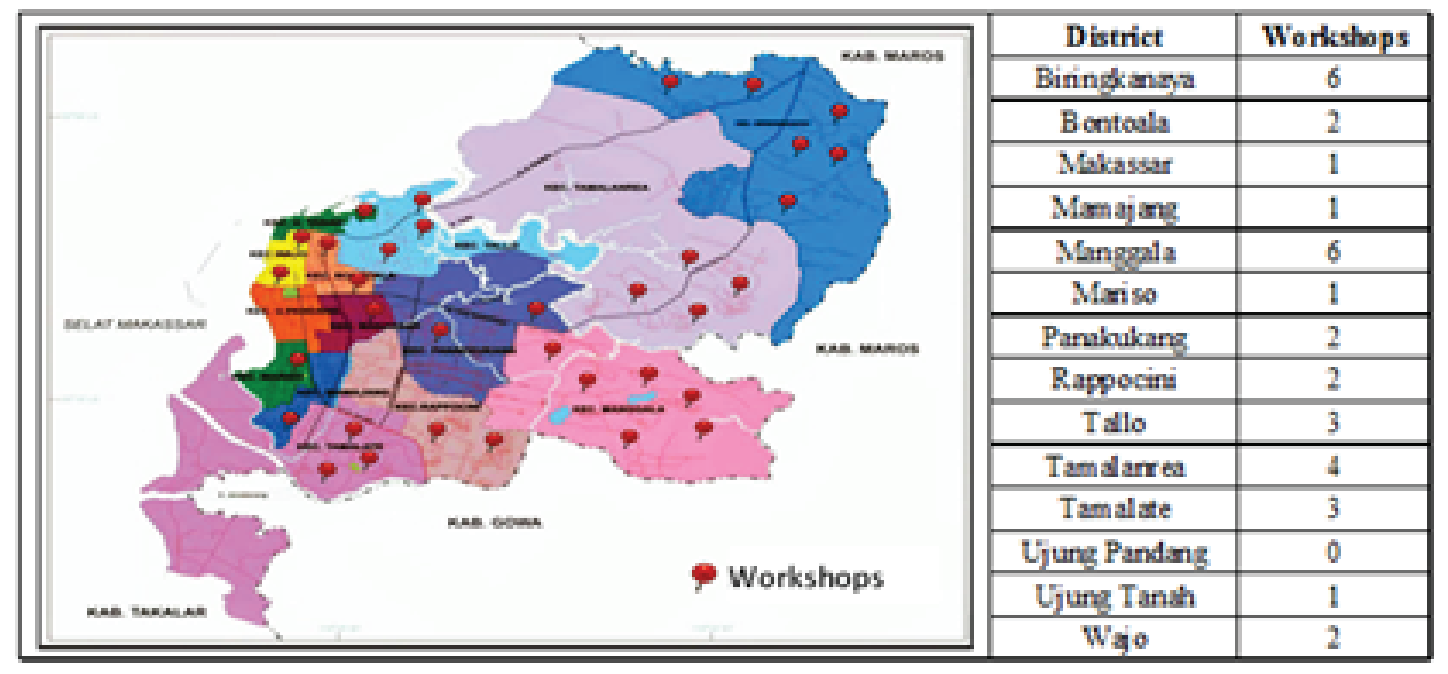

Figure 1: Distribution of welding in Makassar City.

Interviews, direct observation, and questionnaire, respectively, were used to collect data on demographic characteristics, occupational hazards, and musculoskeletal disorder experience. Demographic factors that collected were age, work hour, educational status, work experience, safety training, use of safety tools, also smoking and drinking habit. Working posture assessed using OVAKO Working Analysis System (OWAS) method [12] and level of musculoskeletal disorder (MSDs) complaints using Nordic Body Map [13]. Descriptive statistics were used in data analysis, and bivariate logistic regression was used for correlate between variables.

\section{Results and Discussions}

\subsection{Demographics characteristics}

The mean age of workers was 33.47 (range 18-58) years, all male, 66 percent are married, 78 percent smoke cigarette, 22 percent has drinking habit, and 56 percent 
had grade school education or lower. Details of demographics characteristics can be seen in Table 1.

TABLE 1: Socio-demographics characteristics.

\begin{tabular}{|c|c|c|}
\hline Variables & Number & Percent \\
\hline \multicolumn{3}{|l|}{ Age (in years) } \\
\hline $18-29$ & 31 & $42 \%$ \\
\hline $30-41$ & 23 & $31 \%$ \\
\hline $42-53$ & 15 & $20 \%$ \\
\hline$>54$ & 4 & $5 \%$ \\
\hline \multicolumn{3}{|l|}{ Marital Status } \\
\hline Single & 24 & $33 \%$ \\
\hline Married & 48 & $66 \%$ \\
\hline Divorced & 1 & $1 \%$ \\
\hline \multicolumn{3}{|c|}{ Educational Status } \\
\hline No Education & 2 & $3 \%$ \\
\hline Grade School & 20 & $27 \%$ \\
\hline Junior High & 19 & $26 \%$ \\
\hline Senior High & 17 & $23 \%$ \\
\hline Collage & 12 & $17 \%$ \\
\hline Others & 3 & $4 \%$ \\
\hline \multicolumn{3}{|c|}{ Smoke Cigarette } \\
\hline Yes & 57 & $78 \%$ \\
\hline No & 16 & $22 \%$ \\
\hline \multicolumn{3}{|l|}{ Drink Alcohol } \\
\hline Yes & 16 & $22 \%$ \\
\hline No & 57 & $78 \%$ \\
\hline
\end{tabular}

Some of the findings were similar with other researches which more than 50 percent of Indonesian SMEs welders were ranged 18-41 years old $[3,14]$ and have low educational status whom less than 21 percent have education above senior high school [3].

\subsection{Behavior and the use of personal protective equipment (PPE)}

Working experience of 66 percent welders was over 4 years, corresponded with Dzulfiqar \& Handayani [5] which 59 percent employment was over 5 years. Most of them 
(73\%) worked less than 8 hours a day, but it was different with Ramadhana \& Amir [3] which 74.6 percent of SMEs welders worked in range 7-12 hours/day.
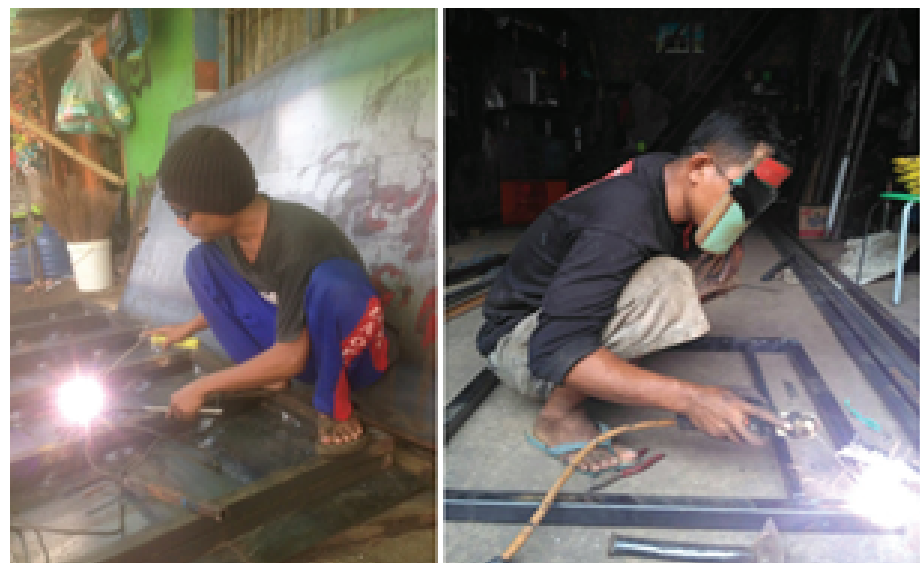

Figure 2: Welder posture.

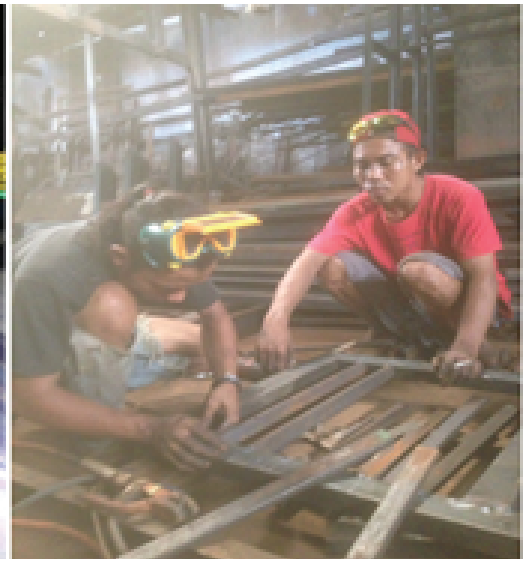

Most of the workers were 95 and 84 percent did not take safety training/course and safety awareness, respectively. This also found in other studies [5, 9, 14], where almost 70 percent of SMEs workers have less knowledge about safety and personal protective equipment (PPE). PPE are treated as luxuries rather than necessities [10]. There were 96 percent of SMEs did not sufficiently provide PPE (Table 2). In average, only 44 percent of workers use the proper equipment, and this similar with Dzulfiqar $\&$ Handayani [5] that 66.7 percent of PPE available, however only 64.9 percent of them used while welders working.

\subsection{Workplace conditions}

Work condition assessed by interview concludes that 63 percent of welders perceived the temperature of their workplace were comfortable, 53 percent fells quite environment, and 66 percent illuminations were good enough to do their job. These imply that workplace of small-scale welding workshops in Makassar were in rather appropriate condition.

\subsection{Worker complaints and posture analysis}

As seen in Figure 2, most of welders do their work in sitting position, bending their knee and back for a long time. This corresponded to Ismaila et al. [15] found that majority of the welders $(58.3 \%)$ claimed that they worked with their arms above the shoulder 
TABLE 2: Worker and behaviors characteristics.

\begin{tabular}{|c|c|c|}
\hline Variables & Number & Percent \\
\hline \multicolumn{3}{|c|}{ Work Experience (in years) } \\
\hline$<1$ & 7 & $9 \%$ \\
\hline $1-4$ & 18 & $25 \%$ \\
\hline$>4$ & 48 & $66 \%$ \\
\hline \multicolumn{3}{|l|}{ Hour work per day } \\
\hline$<8$ & 53 & $73 \%$ \\
\hline$>8$ & 17 & $23 \%$ \\
\hline \multicolumn{3}{|c|}{ Attended Safety Training } \\
\hline Yes & 4 & $5 \%$ \\
\hline No & 69 & $95 \%$ \\
\hline \multicolumn{3}{|l|}{ Safety Awareness } \\
\hline Yes & 12 & $16 \%$ \\
\hline No & 61 & $84 \%$ \\
\hline \multicolumn{3}{|l|}{ PPE Available } \\
\hline Yes & 3 & $4 \%$ \\
\hline No & 70 & $96 \%$ \\
\hline \multicolumn{3}{|l|}{ PPE Used } \\
\hline Welding Mask & 25 & $34 \%$ \\
\hline Safety Helmet & 10 & $14 \%$ \\
\hline Safety Glove & 23 & $32 \%$ \\
\hline Safety Shoes & 34 & $47 \%$ \\
\hline Safety Goggle & 57 & $78 \%$ \\
\hline Supporting Chair & 41 & $56 \%$ \\
\hline APAR availability & 32 & $44 \%$ \\
\hline
\end{tabular}

and/or away from the body, 50 percent of the welders often squat for more than two hours while doing their work and 77.1 percent had to bend or twist the spine.

Nordic body map analysis indicated that 51 percent welder experiencing moderate level prevalence of musculoskeletal complaints (Figure 3) on back (57\%), hip (41\%), forearm (14\%), buttock (11\%), and shoulder ( $8 \%)$. Those complaints separated as discomforts ( $47 \%$ of worker) and pain $(4 \%)$ at their parts of body. This finding is in line with Kurnianto \& Mulyono [16] that workers discomfort site was on hip (92.37\%), shoulder (76.92\%) and leg (76.92\%), and with Malikraj et al. [17] which highest prevalence were back $(81.3 \%)$ and shoulders (32\%). 
TABLE 3: Work conditions.

\begin{tabular}{l|c|c|}
\hline Variables & Number & Percent \\
\hline Temperature & & \\
\hline Comfortable & 46 & $63 \%$ \\
\hline Warm & 21 & $29 \%$ \\
\hline Hot & 5 & $7 \%$ \\
\hline Very Hot & 1 & $1 \%$ \\
\hline Noise & & \\
\hline Quite & 39 & $53 \%$ \\
\hline Rather Noisy & 15 & $21 \%$ \\
\hline Noisy & 11 & $15 \%$ \\
\hline Very Noisy & 8 & $11 \%$ \\
\hline Illumination & & \\
\hline Dark & 0 & $0 \%$ \\
\hline Rather Dark & 13 & $18 \%$ \\
\hline Sufficient & 48 & $66 \%$ \\
\hline Bright & 13 & $18 \%$ \\
\hline Dazzling & 0 & $0 \%$ \\
\hline Blinding & 0 & 0 \\
\hline
\end{tabular}

Posture analyses by OWAS concluded that 55 percent of welders were fall under category 3 (Table 4), similar finding with Mahendra et al. [6] in small-scale workshop, imply that their work postures in high risk which suggests need improvement immediately. Welding in medium enterprises also has risks which 57 and 95 percent of their workers scored 2 OWAS, respectively, study by Nikpeyet al. [11] and Kurnianto \& Mulyono[16].

TABLE 4: OWAS identification.

\begin{tabular}{|c|c|}
\hline OWAS Category & Total \\
\hline Category 1 & 13 \\
\hline Category 2 & 19 \\
\hline Category 3 & 40 \\
\hline Category 4 & 1 \\
\hline
\end{tabular}




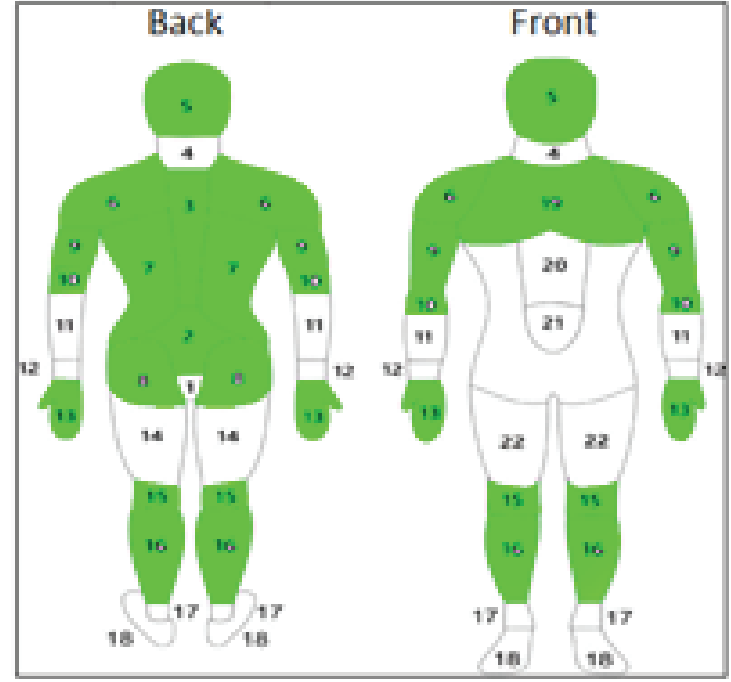

Discomfort

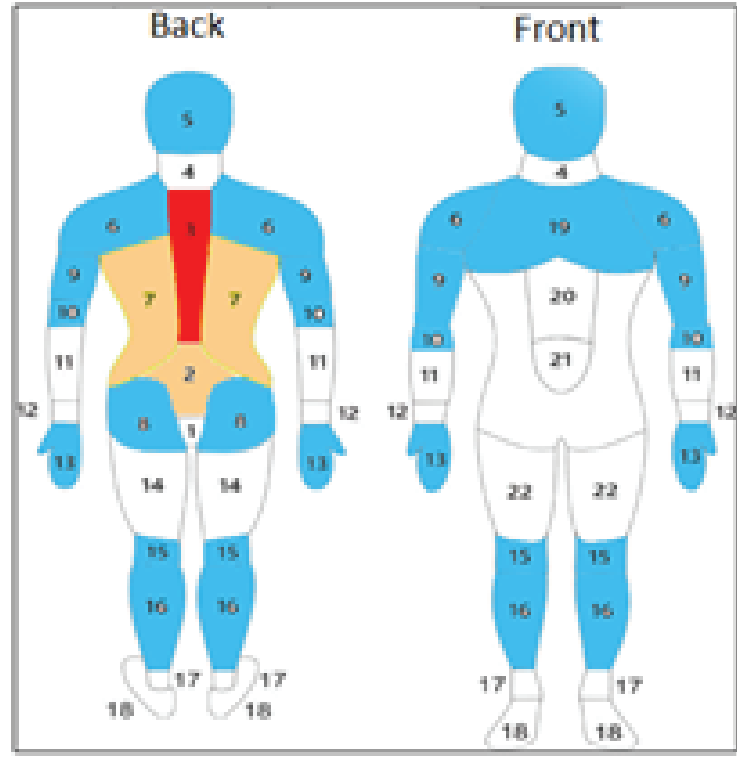

Figure 3: Complaints of discomfort and local pain.

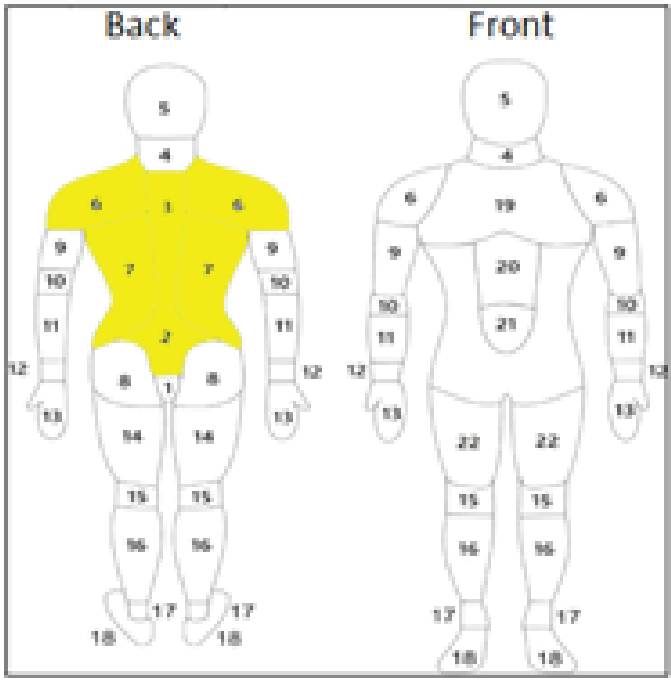

Pain

1 - 10 complaints

11 - 20 complaints

21 - 30 complaints

\subsection{Factor associated with occupational hazards}

The data obtained was processed by using software STATA. The result of bivariate analysis between demographics variables and musculoskeletal complaints provided in Table 5 .

The relationship between ages and the prevalence of complaints is not significant ( $p=0.971)$. This result agreed to Dofina \& Nawawinetu [18] that there is no correlation between ages with the prevalence of subjective complaints MSDs in welding workshop workers. The relationship between educational status and the prevalence of complaints is also not significant $(p=0.489)$. However, Tadesse et al. [9] found that 
TABLE 5: The relationship of social demographic and musculoskeletal disorders.

\begin{tabular}{|l|c|c|c|}
\hline Variables & $\mathbf{z}$ & $\mathbf{p}>|\mathbf{z}|$ & Relations \\
\hline Age & 0.04 & 0.971 & Not Significant \\
\hline Educational Status & -0.69 & 0.489 & Not Significant \\
\hline Employment & 1.04 & 0.301 & Not Significant \\
\hline Hour Work & -1.00 & 0.316 & Not Significant \\
\hline Safety Training & 0.65 & 0.517 & Not Significant \\
\hline Safety Awareness & 0.59 & 0.556 & Not Significant \\
\hline PPE Available & 0.22 & 0.824 & Not Significant \\
\hline Smoking Habit & -0.98 & 0.327 & Not Significant \\
\hline Drink Alcohol & 0.47 & 0.637 & Not Significant \\
\hline Work Posture & -2.17 & 0.030 & Significant \\
\hline
\end{tabular}

workers who attained a higher level of education could have the tendency to change available information into mature stage which increased their awareness of hazards.

Similar tendency also spotted in the relationship between the prevalence of complaints and employment $(p=0.301)$, and with also hours of work $(p=0.316)$. Dofina \& Nawawinetu [18] also found that there was no significant correlation between working period and prevalence of subjective complaints MSDs. Research by Dzulfiqar \& Handayani [5] imply that there was no significant correlation between the employment variable with workers safety behavior. But Das et al. [10] revealed that number of years of welding have good correlation with percentages of welders with eye diseases, regular headache, cardiovascular diseases \& respiratory diseases; and more severely affected than the persons not working in welding shop.

No significant relationship also found between the prevalence of complaints and safety training $(p=0.517)$, and safety awareness $(p=0.556)$. These results contradict with study by Singh \& Singhal [19] that found untrained welders are serious concern in high musculoskeletal disorders risk in welding. Dzulfiqar \& Handayani [5] also highlight that there was a significant relationship between knowledge of safety and safety behavior. Other studies found that hazards awareness significantly associated with the presence of workplace safety regulations [9].

The relationship between availability of PPE and the prevalence of complaints is not significant $(p=0.824)$. These results indicate that the availability of PPE indirectly related to workers complaints, but correlate to behavior of worker safety [5] and safety knowledge [14] in the welding workshop. Study by Salawati [14] shows that wellknowledgeable welders $(76.9 \%)$ tend to use eye protective equipment than the less 
informed workers (36.4\%). Results by Suprianto \& Evendi [8] conclude that there is moderate relationship between compliance of PPE and workplace accident. Workers who have poor conformity to PPE have 2.750 times higher accident risk than workers who obedient to use of PPE.

The prevalence of complaints and smoking habit also has no significant relationship $(p=0.327)$ as well as to the drink alcohol habit $(p=0.637)$. This result agreed to Dofina \& Nawawinetu [18] that there was no correlation between the smoking habit with the prevalence of subjective complaints MSDs in welding workshop workers.

The only factor that have a significant value associated with musculoskeletal symptoms was the working posture $(p=0.030)$. This result support to Dofina \& Nawawinetu [18] that awkward posture have a significant correlation with subjective MSDs complaints $(p=0.003)$ and the study by Jalajuwita \& Paskarini [20] which found working positions have high correlation with prevalence of musculoskeletal complaint.

\section{Recommendation}

Results conclude that small-scale welders in Makassar have high self-reported complaint, which are back and hip discomfort. Bend or squat position while working is the most common factor induced musculoskeletal disorder between welders. Data collected by Dofina \& Nawawinetu [18] obtained that body posture that tends to bend or tilt has a risk of lower back pain 2.58 times greater than the upright posture, while the attitude of combination between bending, tilting, and twisting rising risk to 2.68 times higher. Ergonomics interventions can improve working condition and decrease exposure level [17], focused on eliminating awkward posture of shoulder, back and neck and eliminate static working posture because correlate with subjective MSDs complaints $[15,18]$.

The most successful approaches with outcome to reduce workplace injuries are safety behavior (59.6\%), followed by an ergonomic approach (51.6\%), the last was engineering control approaches (29\%) [21]. As concludes by Dzulfiqar \& Handayani [5] and Salawati [14] there was a significant correlation between attitudes in working with safety behavior and PPE use in welding workshop workers. Proper awareness of welding hazards is important to design safety education program, using different protective tools, and improve efficiency [9].

The existence of PPE is often underestimated by workers [8]. About 72 percent of welders were not clear about hazards of welding and reluctant to accept that prolonged exposure to welding fumes could be fatal [10]. Only a small proportion of welders had 
all the mandatory personal protection equipment. This can be seen in the study that only 4 percent of workers have PPE available, and 44 percent of workers use the PPE even though not the required ones. Another interesting finding of Tadesse et al. [9] was that the odds of hazards awareness between employees that satisfied of their job and who were not. The satisfied employees were aware of hazards more than nine times higher.

Engineering control approaches suggested by Das et al. [10] that welding should be performed in well-ventilated areas and use local-exhaust ventilation toremove fumes and gases at their source in still air. Smoke inhalation risk assessment study [22], for example, by calculating volatility score of each danger chemical agent of a process must be done regularly. Other recommendation by Nikpey et al. [11] in welding workstation, which classified as the heavy works, using electric or pneumatic fixed welding instead of manual welding.

\section{Conclusions}

Welders in this study experiencing numbers of musculoskeletal disorder. OWAS analysis indicated that 55 percent welders fall in the Category 3, which need improvement immediately. The only factor have a significant value associated with musculoskeletal complaints is the working posture. Further research needed within this occupational group to avoid musculoskeletal disorder and increase welder well-being. Some recommendations are suggested to improve working posture and safety behavior, increase protective equipment awareness, also engineering control approaches.

\section{Conflict of interest}

The authors declare that they have no competing interest.

\section{References}

[1] International Labour Organization (ILO). (2014). Hari Keselamatan dan Kesehatan seDunia Mempromosikan budaya keselamatan di usaha kecil menengah di Indonesia.

[2] Lembaga Pengembangan Perbankan Indonesia dan Bank Indonesia. (2015). ProfilBisnis Usaha Mikro, Kecil Dan Menengah (UMKM).

[3] Ramadhana, F. H. and Amir, H. (2012). Persepsi Pengusaha Dan Pekerja UMKMTerhadap Program Jaminan Sosial Nasional. Tim PPRF-BKF-Kementerian Keuangan, 
Laporan Kajian Kesinambungan APBN Atas Program Jaminan Sosial Nasional.

[4] Badan Pusat Statistik. (2016). Statistik Indonesia Tahun. Retrieved from http:// www.bps.go.id

[5] Dzulfiqar, A. and Handayani, P. (2016). Faktor-Faktor Yang Berhubungan Dengan Perilaku Keselamatan Pada Pekerja Bengkel Las di Wilayah Pejompongan Kelurahan Bendungan Hilir Jakarta Pusat Tahun 2016. Undergraduate Theses of Public Health, Fakultas Ilmu Kesehatan, Universitas Esa Unggul.

[6] Mahendra, K. C., Virupaksha G. H., and Gouda A. T. (June 2016) Ergonomic analysis of welding operator postures. International Journal of Mechanical and Production Engineering, vol. 4, no. 6.

[7] Loop, T. V. D. and Andadari, R. K. (2009). Social Security for Informal Economy Workers in Indonesia: Looking for Flexible and Highly Targeted Programmes. Jakarta: International Labour Organization.

[8] Suprianto, R. and Evendi, A. (December 2015). Compliance use of personal protective equipment in las workers in indramayu. Jurnal Kesehatan Masyarakat, vol.1, no. 3 .

[9] Tadesse, S., Bezabih, K., Destaw, B., et al. (2016). Awareness of occupational hazards and associated factors among welders in Lideta Sub-City, Addis Ababa, Ethiopia. Journal of Occupational Medicine and Toxicology.

[10] Das, A., Ahuja, J., and Mandal, A. (July 2015). Occupational exposure and health problems of workers in unauthorised small-scale welding industries in Delhi: $A$ situational analysis. International Journal of Engineering Research \& Technology (IJERT), vol. 4, no. 07.

[11] Nikpey, A., Ghalenoei, M., SafaryVariani, A., et al. (Fall 2013). Musculoskeletal disorders and posture analysis at workstations using evaluation techniques. Journal of Jahrom University of Medical Sciences, vol. 11, no. 3.

[12] Karhu, O., Kansi, P., and Kuorinka, I. (1977). Correcting working postures in industry: A practical method for analysis. Applied Ergonomics, vol. 8, pp. 199-201.

[13] Kuorinka, I., Jonsson, B., and Kilbom, A. (1987). Standardized nordic questionnaires for the analysis of musculoskeletal symptoms. ApplErgon, vol. 18, pp. 233-237.

[14] Salawati, L. (December 2015). Analisis penggunaan alat pelindung mata pada pekerja las. Jurnal Kedokteran Syiah Kuala, vol. 15, no. 3.

[15] Ismaila, S. O., Akanbi, O. G., Daniel, O. S., et al. (2010). Ergonomic evaluation of welding workplace. Human Factors in Organizational Design and Management $-X$.

[16] Kurnianto, R. Y., Mulyono. (January-April 2014). Gambaran Postur kerja dan resiko terjadinya muskuloskeletal pada pekerja bagian welding di area workshop bay 4.2 
pt. alstom power energy systems Indonesia. The Indonesian Journal of Occupational Safety, Health and Environment, vol. 1, no. 1, pp. 61-72.

[17] Malikraj, S., Senthil Kumar, T., and Ganguly A. K. (July-September 2011). Ergonomic intervention on musculoskeletal problems among welders. International journal of Advanced Engineering Technology (IJAET), vol. II, no. III, pp. 33-35.

[18] Dofina, B. and Nawawinetu, E. D. (2016). Beberapa faktor yang berhubungan dengan keluhan subyektif msds pada bengkel las X. Jurnal Penelitian AKBID Mandiri Gresik, pp. 24-36.

[19] Singh, B. and Singhal, P. (2016). Work related musculoskeletal disorders (wmsds) risk assessment for different welding positions and processes, in 14th International Conference on Humanizing Work and Work Environment HWWE, pp. 264-267.

[20] Jalajuwita, R. N. and Paskarini, I. (January-June 2015). Hubungan posisi kerja dengan keluhan muskuloskeletal pada unit pengelasan PT. X Bekasi. The Indonesian Journal of Occupational Safety and Health, vol. 4, no. 1, pp. 33-42.

[21] Geller, E.S. (2001). The Psychology of Safety Handbook. Boca Raton: Lewish Publisher.

[22] Amza, G., Nitoi, D. F., Petrescu, V. D., et al. (2017). Contributions to risk assessment in the departments of welding mechanical engineering companies, in MATEC Web of Conferences 121, MSE 2017. 